\title{
3 Perspectivas para futuros debates
}

Não caberia aos coordenadores concluir este debate, mas, ao contrário, incentivar sua propagação entre todos os atores - incluindo a opinião pública - do potencial e dos desafios que teremos pela frente e de como poderemos nos preparar para o pós-pandemia.

A pandemia, infelizmente, não se tornará apenas uma lembrança cruel, como aconteceu com a gripe espanhola. Mudanças estruturais e de comportamento acompanharão o período de convivência com a esperada erradicação do vírus, e algumas persistirão após esse tão esperado momento. O que nos cabe é garantir que todo o sofrimento dê lugar a um equilíbrio mais harmônico e eficiente entre os atores da hélice quádrupla, e que isso nos prepare para viver melhor e ter uma capacidade de resposta ainda melhor e resiliente. Os painelistas foram unânimes em apontar essa direção, ainda que por ângulos distintos.

Convidamos a todos a continuar este debate. 